\title{
Effects of Stock Plant Etiolation, Shading, Banding, and Shoot Development on Histology and Cutting Propagation of Carpinus betulus L. fastigiata
}

\author{
Brian K. Maynard ${ }^{1}$ \\ Department of Plant Sciences, University of Rhode Island, Kingston, RI 02881 \\ Nina L. Bassuk ${ }^{2}$ \\ Department of Floriculture and Ornamental Horticulture, Cornell University, Ithaca, NY 14853
}

Additional index words. European hornbeam, adventitious root formation

\begin{abstract}
New shoot growth of Carpinus betulus L. fastigiata was subjected to stock plant etiolation and stem banding (a 2.5-cm square of Velcro applied to the shoot base) treatments and sampled for histological study at intervals over a 16week period of shoot development following etiolation. Effects of partial shading on histology of the stem were also investigated. Numerous histological changes were noted with stem development and stock plant treatment. Among these were a reduction in lignification of the secondary xylem and thickness of the periderm, and an increase in the percentage of sclereid-free gaps in the perivascular sclerenchyma with etiolation. Concomitant propagation studies revealed significant etiolation, shading, and banding effects on rooting percentages and root numbers. Rooting capacity was modelled using linear combinations of the widths of nonlignified secondary xylem, cortical parenchyma and periderm, as well as the percentage of gaps in the sclerenchymatic sheath remaining free of sclereids. It is proposed that the development of sclereids in potential rooting sites reduces rooting potential. The exclusion of light during initial shoot development retards sclereid development by up to 3 months following treatment, which correlates well with observed increases in the rooting potential of etiolated stems.
\end{abstract}

The histological origins of adventitious root primordia have been studied in many woody and herbaceous plant species. Past reviews agree that most plant species form roots from cells of the phloem ray parenchyma immediately outside the vascular cambium and in association with interfascicular rays (Haissig, 1973; Lovell and White, 1986).

The rooting capacity of stem cuttings varies with plant species, maturity, time of year and other factors. Furthermore, several histological features are often associated with rooting, including the development of fibers and sclereids making up the perivascular sclerenchyma sheath, a support structure found in virtually all woody dicotyledons (Esau, 1977). The heavy lignification and extensive development of this fiber sheath has been correlated with poor rooting, and has been proposed to act as a mechanical barrier to root initiation (Ciampi and Gellini, 1958; Goodin, 1965; Edwards and Thomas, 1980).

Several studies testing the barrier hypothesis have shown that roots, once initiated, grow through most sclerenchymatous tissues external to the site of root initiation (Sachs et al., 1964; Girouard, 1967; Brutsch et al., 1977; Davies et al., 1982). Furthermore, while the mechanical barrier hypothesis predicts that roots would initiate centripetal to the fiber bands and then fail to emerge, roots simply do not initiate in many difficult-to-root plant species; hence the barrier hypothesis has been largely discounted. Yet the fact remains that where extensive sclerification within the cortex or pericycle has taken place, rooting generally does not occur (White and Lovell, 1984b). Surveys of root formation in forest trees

Received for publication 15 Aug. 1995. Accepted for publication 12 Feb. 1996. Technical contribution no. 3225 of the Rhode Island Agricultural Experiment Station. We are grateful to Schichtel's Nursery for donating plant material. Use of trade names does not imply endorsement of products named nor criticism of similar products not mentioned. The cost of publishing this paper was defrayed in part by the payment of page charges. Under postal regulations, this paper therefore must be hereby marked advertisement solely to indicate this fact.

${ }^{1}$ Assistant professor.

${ }^{2}$ Professor
(Nanda et al., 1970) and ornamentals (Bose and Mondal, 1975; White and Lovell, 1984a) note that easily rooted species often display rays opening directly onto the cortex. Difficult-to-root species show heavier lignification of the phloem fibers, more sclereid development, a less active cambium and fewer ray cells in active growth, yielding a nearly continuous ring of sclerenchyma.

Cells destined to become sclereids in the course of stem differentiation are a part of, or immediately adjacent to, putative loci of adventitious root initiation, and therefore are likely to influence the early events of root initiation. Their differentiation to nonliving sclereids might be expected to reduce rooting potential by reducing the number of potential initiation sites. White and Lovell (1984a, 1984b) observed with Agathis and Griselinia that, as the stem matured, the cortex filled with sclerenchyma and resin canals, leaving few cells as potential root initiation sites. Beakbane (1969) noted that easy-to-root clones of Camellia remained nonlignified.

Early histological studies of etiolated stems found major differences in fiber and sclereid development. Reid (1923) noted a delay in sclereid formation with localized etiolation (stem blanching) of camphor (Camphora officinarum Nees.), and the lack of a complete perivascular sheath in etiolated shoots. Smith (1924) prevented the lignification of stems of Clematis using localized etiolation. The meristematic activity of the rays also increased with etiolation. Beakbane (1961) found that the differentiation of the phloem parenchyma to sclerenchyma was retarded by shading or etiolation.

Past work has shown that etiolation reduces or delays sclereid formation in avocado (Persea americana Mill.) (Gomez et al., 1973) and chestnut (Castanea sativa Mill.) (Vieitez, 1974; Rinallo et al., 1987). Doud and Carlson (1977) determined that the percentage of phloem rays blocked by sclereids at the pericycle was negatively correlated $\left(r^{2}=-0.94\right)$ with rooting in four cultivars of Malus. Etiolation reduced the percentage of sclereid-blocked rays by 10 percentage points, and increased rooting from an average of $6 \%$ to $>72 \%$. 
Schmidt (1986) found that etiolating stems of Tilia tomentosa Moench. improved rooting and increased stem diameter, cortical width, number of dilated phloem rays, and width of xylem rays. Etiolation also decreased the number, tissue percentage and degree of lignification of perivascular fibers. Following a 6-week greening period, initially etiolated stems were less sclerified, had wider rays, and a wider cortex than light-grown stems, and looked, histologically, like light-grown stems sampled soon after budbreak.

The objectives of the following studies were to develop correlations of histological changes with rooting capacity of stem cuttings of upright European hornbeam, Carpinus betulus L. fastigiata. Softwood cuttings were found in earlier work to respond positively to the stock plant treatments of etiolation and stem banding (Maynard and Bassuk, 1992). In the first study (Expt. 1) we examined changes occurring with the development of the plant stem over a 4-month growing period, which correlated well with a decline in rooting capacity. In the same study etiolation and stem banding, which each promoted rooting, were used to correlate treatment effects on stem anatomy with rooting response. In the second study (Expt. 2) stock plant shading, which also improved rooting, was used to further correlate anatomical changes with rooting success.

\section{Materials and Methods}

\section{Stock plant culture}

Twenty dormant, bare root, 5-year-old stock plants of upright European hornbeam (Schichtel's Nursery, Orchard Park, N.Y.; grafted on seedling rootstocks) were potted into 30-L (Expt. 1) or 40-L (Expt. 2) plastic containers containing a medium of 1 sandy loam soil : 1 sphagnum peat : 1 perlite (by volume) and placed in cold storage at $4 \pm 1{ }^{\circ} \mathrm{C}$ for 12 weeks before each experiment, to satisfy the dormancy requirement. Following cold storage, plants were transferred to a glass greenhouse $\left(16 \pm 3{ }^{\circ} \mathrm{C}\right.$ day/night).
Incandescent lamps $(100 \mathrm{~W})$ suspended $3 \mathrm{~m}$ above the stock plants and spaced $1 \mathrm{~m}$ apart were used daily from 4:00 PM to 12:00 AM to extend the natural photoperiod to $16 \mathrm{~h}\left[2 \pm 0.1 \mu \mathrm{mol} \cdot \mathrm{m}^{-2} \cdot \mathrm{s}^{-1}\right.$ at midplant level measured using a quantum sensor (LI-190 SB; LICOR, Lincoln, Neb) (sensor error $\leq 0.1 \mu \mathrm{mol} \cdot \mathrm{m}^{-2} \cdot \mathrm{s}^{-1}$ )]. Stock plants were fertilized to runoff weekly with $200 \mathrm{mg}$ N/L from a 20N-4.4P-16.6K water soluble fertilizer (Grace-Sierra Horticultural Products, Milpitas, Calif.).

\section{Etiolation and banding effects on rooting (Expt. 1)}

Stock plants forced for Expt. 1 began to break bud within 1 week, at which time 10 of the plants were selected randomly and placed for etiolation in a black cloth covered structure, located in the same greenhouse, with 0.5 to $1.0 \mathrm{~m}$ between the plants and covering. Light-grown stock plants remained uncovered and grew under full irradiance. The etiolation structure excluded $>99 \%$ of incident visible radiation. Light was excluded from developing shoots until they were 5 to $10 \mathrm{~cm}$ long, which required $7 \mathrm{~d}$. After this time, stem bands were applied to the proximal ends of half the shoots selected at random throughout the crown of each stock plant. The etiolation cover then was removed gradually, to prevent scorching of the etiolated shoots, by incrementally raising the curtain edge over the next $5 \mathrm{~d}$. Stem banding involved placing the base of new shoot growth between the hook and wool layers of 2.5 $\times 2.5-\mathrm{cm}$ strips of Velcro, and pressing on the stems so that the bands would not slip from position after application (Maynard and Bassuk, 1987). Light-grown and etiolated shoots were banded at the same time. In this experiment, the transition of etiolated to green growth, which occurred on exposure to light, is referred to as greening. The beginning of the greening period coincided with the termination of the etiolation period, $7 \mathrm{~d}$ after budbreak. Therefore, light-grown shoots were exposed to ambient irradiance $7 \mathrm{~d}$ longer than etiolated shoots. Samples for anatomical study were taken every 2 weeks for 16 weeks following etiolation.

Table 1. Significance of treatment main effects and interactions (Expt. 1). A significant value of $P$ for the covariate indicates that the covariate was used in the calculation of means and statistical analysis of treatment effects. $\mathrm{A}=$ shoot age $; \mathrm{E}=$ etiolation; $\mathrm{B}=\operatorname{stem~banding;} 1^{\circ}=$ primary; $2^{\circ}=$ secondary.

\begin{tabular}{|c|c|c|c|c|c|c|c|c|}
\hline \multirow[b]{2}{*}{ Parameter } & \multicolumn{3}{|c|}{ Main effects } & \multicolumn{4}{|c|}{ Interactions } & \multirow{2}{*}{$\begin{array}{c}\text { Covariate } \\
\text { shoot } \\
\text { diam }\end{array}$} \\
\hline & $\mathrm{A}$ & $\mathrm{E}$ & $\mathrm{B}$ & $\mathrm{E} \times \mathrm{B}$ & $\mathrm{A} \times \mathrm{E}$ & $\mathrm{A} \times \mathrm{B}$ & $\mathrm{A} \times \mathrm{E} \times \mathrm{B}$ & \\
\hline \multicolumn{9}{|l|}{ Rooting } \\
\hline Percent rooting & $0.0001^{*}$ & $0.0001^{*}$ & $0.0001^{*}$ & 0.15 & $0.0001^{*}$ & $0.0009^{*}$ & 0.14 & $0.025^{*}$ \\
\hline Roots/rooted cutting & $0.0018^{*}$ & $0.0001^{*}$ & $0.0003^{*}$ & $0.011^{*}$ & $0.0001^{*}$ & 0.52 & $0.024^{*}$ & 0.054 \\
\hline \multicolumn{9}{|l|}{ Measurement } \\
\hline Stem diameter $(\mathrm{mm})$ & 0.22 & 0.28 & 0.64 & 0.26 & $0.057^{*}$ & 0.42 & $0.033^{*}$ & --- \\
\hline \multicolumn{9}{|l|}{ Width of $(\mu \mathrm{m})$} \\
\hline $1^{\circ}$ xylem & $0.0038^{*}$ & 0.73 & 0.89 & 0.48 & $0.003^{*}$ & 0.93 & 0.80 & 0.26 \\
\hline $2^{\circ}$ xylem & $0.0032^{*}$ & 0.99 & $0.021^{*}$ & 0.11 & 0.65 & 0.65 & 0.41 & $0.0001^{*}$ \\
\hline Phloem & 0.14 & 0.084 & 0.57 & 0.45 & 0.28 & 0.77 & 0.07 & $0.0001^{*}$ \\
\hline Fiber bundles & $0.0005^{*}$ & 0.63 & 0.36 & 0.23 & 0.27 & 0.29 & $0.048^{*}$ & $0.0016^{*}$ \\
\hline Cortex & $0.0025^{*}$ & $0.050^{*}$ & 0.48 & 0.67 & 0.58 & 0.33 & 0.44 & $0.013^{*}$ \\
\hline Collenchyma & 0.37 & 0.58 & 0.16 & 0.44 & 0.22 & 0.26 & 0.098 & 0.087 \\
\hline Periderm & $0.029^{*}$ & $0.008^{*}$ & 0.21 & 0.82 & 0.18 & 0.082 & 0.12 & $0.004^{*}$ \\
\hline \multicolumn{9}{|l|}{ Number of } \\
\hline Fiber bundles & $0.0048^{*}$ & 0.50 & 0.98 & 0.64 & 0.40 & 0.72 & 0.13 & $0.0001^{*}$ \\
\hline Sclereids & $0.0003^{*}$ & 0.87 & 0.30 & 0.54 & $0.023^{*}$ & 0.41 & $0.006^{*}$ & $0.0001^{*}$ \\
\hline \multicolumn{9}{|l|}{ Percentage of } \\
\hline Nonlignified $2^{\circ}$ xylem & $0.0001^{*}$ & $0.0035^{*}$ & 0.21 & 0.89 & 0.082 & 0.68 & 0.56 & 0.20 \\
\hline Sclereid-free gaps & $0.0001^{*}$ & $0.0001^{*}$ & 0.41 & 0.95 & 0.055 & 0.17 & 0.51 & $0.015^{*}$ \\
\hline
\end{tabular}


To determine etiolation and banding effects on rooting capacity, cuttings were taken every 2 weeks for 16 weeks from the start of the greening period by severing shoots at the base of the new growth. Banded shoots were cut immediately proximal to the Velcro band and the bands were removed. Nonbanded shoots were cut at a similar point on shoots selected throughout the stock plant crown. All cuttings were trimmed to a length of 7 to $10 \mathrm{~cm}$ with three leaves per cutting (terminal growth removed). Cuttings were immersed for $10 \mathrm{~min}$ in an aqueous solution of $3 \alpha, 4,7,7 \alpha$-tetrahydro2-[(trichloromethyl) thiol]-1H -isoindole-1,3(2H)-dione (Captan $50 \mathrm{WP})$ at $0.25 \mathrm{~g} \cdot \mathrm{L}^{-1}(\mathrm{w} / \mathrm{v})$, placed in polyethylene bags, and stored at $5 \pm 1{ }^{\circ} \mathrm{C}$ for $1 \mathrm{~h}$ before insertion into the rooting medium. The basal $1 \mathrm{~cm}$ of the prepared cuttings were then dipped for $5 \mathrm{~s}$ into 9.8 mM IBA in 50\% aqueous ethanol, allowed to air dry for $15 \mathrm{~min}$, and distributed randomly into eight replicate groups of seven cuttings each. Cuttings were inserted about $2 \mathrm{~cm}$ deep, in a completely randomized design, into a raised greenhouse bench containing a 13-cm-deep unheated 1 peat : 2 perlite (by volume) rooting medium, and were rooted under intermittent mist ( 6 s every $8 \mathrm{~min}$ from 6:00 AM to 8:30 PM daily). A 16-h photoperiod was provided by $60-\mathrm{W}$ incandescent lamps suspended $1 \mathrm{~m}$ above the medium and spaced $1 \mathrm{~m}$ apart $\left(5 \pm 0.1 \mu \mathrm{mol} \cdot \mathrm{m}^{-2} \cdot \mathrm{s}^{-1}\right.$ additional irradiance at cutting level). Air temperatures in the propagation house were maintained at $20 \pm 5{ }^{\circ} \mathrm{C}$; Chicopee shade cloth (Lumite, Gainesville, Fla.) with $50 \%$ light transmission was used to shade the cuttings.

\section{Shading effects on rooting (Expt. 2)}

Stock plants forced for Expt. 2 began to break bud after 25 days. Following budbreak plants to be etiolated or shaded were enclosed in structures covered with black cloth or shade cloth with 0.5 to 1.0 $\mathrm{m}$ separating the plants and coverings. Light-grown stock plants remained uncovered and grew under ambient irradiance $(0 \%$ shade). Shading was arranged to exclude $50 \%$ (one layer $50 \%$ shade cloth), $75 \%$ (two layers 50\% shade cloth), 95\% (one layer $95 \%$ shade cloth) or $>99 \%$ (black cloth) of ambient irradiance.

Stock plants receiving shade treatments were shaded until cuttings were collected, $25 \mathrm{~d}$ after budbreak. Etiolation was applied only until developing shoots were 5 to $10 \mathrm{~cm}$ long, i.e., $15 \mathrm{~d}$. At this time, the black cloth was removed gradually over the next $3 \mathrm{~d}$, and etiolated shoots were allowed to green without shading until cuttings were collected for rooting. Cuttings and anatomical samples were collected from all treatments $10 \mathrm{~d}$ following etiolation, $25 \mathrm{~d}$ after budbreak.

Cuttings were collected by severing shoots at the base of the new growth and prepared as described in Expt. 1. The basal $1 \mathrm{~cm}$ of the cuttings was dipped for $5 \mathrm{~s}$ into $4.9 \mathrm{~mm}$ IBA in $50 \%$ aqueous ethanol, allowed to air dry for $15 \mathrm{~min}$, and distributed randomly into eight replicate groups of eight cuttings each before insertion into the rooting medium, as described previously.

\section{Statistical analysis}

Recording of rooting data and statistical analysis. Cuttings were evaluated after $30 \mathrm{~d}$ for percent rooting, number of roots per rooted cutting and root length per rooted cutting (root length data not presented; see Maynard and Bassuk, 1992, for a complete analysis of rooting data). A cutting was considered rooted if it possessed one or more roots $>1 \mathrm{~mm}$ long. Data of Expt. 1 were analyzed as an $8 \times 2 \times 2$ factorial of shoot age, etiolation and banding treatment (Tables 1-3).

Data of Expt. 2 were analyzed using linear regression of the $0 \%$ to $95 \%$ shade level responses (Table 4). In this study, etiolation was evaluated only as an initial stock plant treatment because etiolated growth needed to green before being used as cutting material to avoid injury from high light intensity or desiccation. Hence, the responses of cuttings taken from initially etiolated shoots were not included in regressions of rooting on shade level. Responses of etiolated cuttings were compared with those of each

Table 2. Rooting responses and anatomical measurements of Carpinus betulus L. 'fastigiata' stems in response to shoot development, stock plant etiolation and stem banding (Expt. 1). Shoot age data averaged across all stock plant treatments and stock plant data averaged across shoot age. L $=$ light grown $; \mathrm{E}=$ etiolated $\mathrm{B}=$ velcro banded $; 1^{\circ}=$ primary $; 2^{\circ}=$ secondary.

\begin{tabular}{|c|c|c|c|c|c|c|c|c|}
\hline \multirow[b]{2}{*}{ Parameter } & \multicolumn{4}{|c|}{ Shoot age (weeks) } & \multicolumn{4}{|c|}{ Stock plant treatment } \\
\hline & 4 & 8 & 12 & 16 & $\mathrm{~L}$ & $\mathrm{~L}+\mathrm{B}$ & $E$ & $E+B$ \\
\hline \multicolumn{9}{|l|}{ Rooting $^{\mathrm{Z}}$} \\
\hline Percent rooting & 90 & 84 & 46 & 6 & 44 & 54 & 60 & 73 \\
\hline Roots/rooted cutting & 5 & 5 & 4 & 3 & 3 & 4 & 4 & 6 \\
\hline \multicolumn{9}{|l|}{ Measurement $^{\mathrm{y}}$} \\
\hline Stem diameter $(\mathrm{mm})$ & 2.3 & 2.5 & 2.5 & 2.2 & 2.2 & 2.4 & 2.3 & 2.3 \\
\hline \multicolumn{9}{|l|}{ Width of $(\mu \mathrm{m})$} \\
\hline $1^{\circ}$ xylem & 27 & 19 & 18 & 18 & 20 & 22 & 21 & 20 \\
\hline $2^{\circ}$ xylem & 448 & 497 & 550 & 549 & 554 & 468 & 519 & 503 \\
\hline Phloem & 60 & 60 & 68 & 62 & 65 & 65 & 62 & 58 \\
\hline Fiber bundles & 71 & 66 & 58 & 56 & 61 & 66 & 63 & 62 \\
\hline Cortex & 100 & 88 & 88 & 77 & 86 & 82 & 92 & 91 \\
\hline Collenchyma & 41 & 42 & 48 & 53 & 47 & 42 & 53 & 43 \\
\hline Periderm & 42 & 53 & 50 & 55 & 56 & 53 & 48 & 43 \\
\hline \multicolumn{9}{|l|}{ Number of } \\
\hline Fiber bundles & 25 & 28 & 28 & 34 & 29 & 30 & 28 & 28 \\
\hline Sclereids & 38 & 149 & 127 & 185 & 118 & 127 & 107 & 145 \\
\hline \multicolumn{9}{|l|}{ Percentage of } \\
\hline Nonlignified $2^{\circ}$ xylem & 36 & 22 & 14 & 10 & 19 & 17 & 24 & 22 \\
\hline Sclereid-free gaps & 78 & 38 & 59 & 31 & 34 & 44 & 64 & 69 \\
\hline
\end{tabular}

${ }^{\mathrm{Z}}$ Rooting means based on eight replicates of seven cuttings each. Rooting evaluated after $30 \mathrm{~d}$.

${ }^{\mathrm{y}}$ Anatomical means based on four measurements of five samples. 
shading level and the light grown control using a two-sample unpaired $t$ test. Percentage data were arcsine transformed before analysis (Snedecor and Cochran, 1980).

Recording anatomical data and statistical analysis. Anatomical data from Expts. 1 and 2 reflect four measurements taken on each of five samples from each treatment. In banded stems two 1$\mathrm{cm}$ samples were prepared, the first sample comprised the blanched (stock plants grown in full light) or etiolated (stock plants initially etiolated ) zone while the second sample, distal to the banded zone, served as a check of banding effects. Samples were fixed in formalin-acetic acid-ethanol for 1 week, dehydrated in an ethanol-tertiary butyl alcohol series and embedded in TissuePrep paraffin embedding media (Fisher Scientific, Pittsburgh). Transverse and longitudinal sections were cut at $20 \mu \mathrm{m}$ on a rotary microtome and stained with safranin and fast green (Johansen, 1940). Sections were observed with a stereomicroscope (model BH-2; Olympus Optical Co., LTD, Tokyo) fitted with an Olympus C-35 camera.

A calibrated reticle was used to measure stem diameter and widths of the primary, secondary and nonlignified secondary xylem, the phloem, perivascular fiber bundles, cortical parenchyma, collenchyma and periderm. Counts were made of the number of discrete perivascular fiber bundles, sclereids lying within the perivascular sclerenchyma sheath, and the percentage of gaps in the sheath remaining free of sclereids. The percentage of nonlignified secondary xylem was calculated by dividing the width of nonlignified secondary xylem by the total width of the secondary xylem. Anatomical descriptions are based on terminology developed by Esau (1977).

Anatomical data of Expt. 1 were subjected to analysis of variance using the PROC GLM procedure of SAS (SAS Institute, 1985) using stem diameter as a normalizing covariate. Stem development, etiolation, banding and position within the stem were analyzed as main effects and interactions (Table 1). Each dependent variable was also regressed on stem diameter to determine the suitability of stem diameter as a covariate. Data of the percentage of sclereid-free gaps in the sclerenchyma sheath and percentage of nonlignified secondary xylem were arcsine transformed before analysis. For the sake of brevity only the data of weeks $4,8,12$, and 16 are presented in Table 2 . Anatomical data of Expt. 2 were analyzed by regression against shade level with stem diameter used as a covariate as outlined in Expt. 1.

The modelling of anatomical effects on rooting percentages and root number per rooted cutting was accomplished using the PROC STEPWISE and PROC RSQUARE multivariate regression analysis procedures of SAS (SAS Institute, 1985). Residuals were analyzed by plotting against dependent variables (analysis not shown).

\section{Results}

\section{Experiment 1: Shoot development, etiolation, and banding effects on stem anatomy}

Qualitative observations. The wood of upright European hornbeam possesses a diffuse-porous architecture with diffuse apotracheal xylem parenchyma. Ray structure is nonstoried and tension wood was evident in most sections. The initial vascular arrangement was polyarchal with 10 to 12 fascicles.

Within 7 to $14 \mathrm{~d}$ of budbreak, an interfascicular vascular cambium developed within the interfascicular parenchyma in new shoot growth. In light-grown stems, the secondary xylem stained positively for lignin. Capping the fascicular groups, centrifugal to the phloem, were discrete bundles of pericyclic fibers, about 6 cells deep by 10 cells wide. These fibers were cytoplasmic, secondarily thickened, and lignified. Centrifugal to these fiber bundles lay a four-cell layer of cortical parenchyma, a two- to four-cell-thick layer of lacunar collenchyma with unevenly thickened, nonlignified cell walls, and an intact periderm. Etiolated stems at this initial sampling date, $7 \mathrm{~d}$ after the end of the etiolation treatment and the start of the greening period, had less secondary xylem and were less lignified. The pericyclic fibers of etiolated stems were also cytoplasmic, but lacked secondary thickening or lignification. The collenchyma, vascular cambium and epidermis were similar to that of light-grown stems.

Table 3. Effects of shoot development, stock plant etiolation and stem banding treatments on rooting and the percentage of sclereid-free gaps in the pericycle for cuttings of Carpinus betulus L. 'fastigiata' (Expt. 1). Etiolation applied for $7 \mathrm{~d}$, banding with velcro for 2 to 16 weeks. LG = lightgrown; ET = etiolated.

\begin{tabular}{|c|c|c|c|c|c|c|c|c|}
\hline \multirow[b]{2}{*}{ Parameter } & \multicolumn{8}{|c|}{ Shoot age (weeks) } \\
\hline & 2 & 4 & 6 & 8 & 10 & 12 & 14 & 16 \\
\hline \multicolumn{9}{|l|}{$\overline{\text { Percent rooting }^{2}}$} \\
\hline LG, - band & 88 & 82 & 50 & 69 & 46 & 17 & 7 & 0 \\
\hline $\mathrm{LG},+$ band & 98 & 87 & 71 & 81 & 48 & 38 & 7 & 7 \\
\hline ET, - band & 91 & 93 & 88 & 90 & 70 & 41 & 8 & 1 \\
\hline $\mathrm{ET},+$ band & 91 & 97 & 90 & 98 & 75 & 89 & 28 & 16 \\
\hline \multicolumn{9}{|c|}{ Roots/rooted cutting } \\
\hline LG, - band & 4 & 3 & 3 & 4 & 3 & 2 & 2 & $--^{y}$ \\
\hline $\mathrm{LG},+$ band & 6 & 6 & 4 & 4 & 3 & 6 & 2 & 2 \\
\hline $\mathrm{ET}$, - band & 5 & 5 & 7 & 4 & 3 & 3 & 2 & 1 \\
\hline $\mathrm{ET},+$ band & 7 & 8 & 7 & 7 & 4 & 5 & 4 & 3 \\
\hline \multicolumn{9}{|c|}{ Percentage of sclereid-free gaps ${ }^{x}$} \\
\hline $\mathrm{LG},-$ band & 94 & 70 & 17 & 12 & 20 & 33 & 4 & 22 \\
\hline $\mathrm{LG},+$ band & 96 & 66 & 17 & 8 & 35 & 50 & 39 & 39 \\
\hline $\mathrm{ET},-$ band & 88 & 91 & 81 & 44 & 66 & 94 & 19 & 31 \\
\hline $\mathrm{ET},+$ band & 91 & 84 & 56 & 87 & 66 & 58 & 73 & 34 \\
\hline
\end{tabular}

${ }^{\mathrm{z}}$ Rooting data based on eight replicates of seven cuttings each. Rooting evaluated after $30 \mathrm{~d}$.

${ }^{\mathrm{y}}$ No cuttings rooted.

${ }^{\mathrm{x}}$ Anatomical means based on four measurements of five samples. 
Four weeks after budbreak, the vascular cambium of lightgrown plants had become continuous about a lignified pith, producing files of xylem vessels, tracheids, and fibers (Fig. 1A). The phloem region was divided by medullary rays extending from the pith, through the xylem, to the cortex. To the outside of the phloem and medullary rays (pericycle region) of light-grown stems, two types of lignified cells interspersed to form a more or less continuous band of sclerenchyma in the perivascular region. The first of these were the pericyclic fibers, now heavily lignified, secondarily thickened and devoid of cytoplasm. The second cell type were characteristically isodiametric, pitted, well-lignified and also devoid of cytoplasm, and appeared to have developed from cells of the medullary rays where they abutted the cortical parenchyma. This second cell type fits the description of brachysclereids (stone cells) given by Esau (1977). After 4 to 6 weeks greening, initially etiolated stems looked very much as they had at the first sampling date, except that the vascular cambium had become continuous and formed files of lignified xylem. In sharp contrast to lightgrown stems, only an occasional brachysclereid was evident in the pericycle of previously etiolated stems 4 weeks following budbreak. Phloem fiber bundles stained lightly for lignin at this time.

After 8 weeks greening, the stems of etiolated plants were similar in many respects to light-grown stems. However, striking differences were apparent in the development of sclereids, which for the most part remained absent (Fig. 1B). Thus, pericyclic fibers in initially etiolated stems were interspersed not by sclereid cells but by nonlignified, cytoplasmic, cortical and phloem ray parenchyma.

After 12 to 16 weeks, light-grown stems exhibited extensive secondary xylem formation with numerous rays traversing the xylem, vascular cambium and phloem. After expanding in width within the phloem, the majority of the phloem rays were terminated in clusters of sclereids filling the areas among pericyclic fibers, which by this time were dispersed into many groups of 2 to 10 cells each. Previously etiolated stems sampled at this time began to show varying degrees of sclereid development. When sclereids were present in etiolated stems their distribution was similar to that of light-grown stems. With the exception that several etiolated stems lacked sclereids entirely, etiolated stems differed little from light-grown stems at this time.

The banding of light-grown stems had little effect on stem anatomy. Of note was the tearing of the periderm by the hooks of the Velcro, and in some instances extensive callusing and wound response (lignified callus, wound periderm, crushed cells) under areas of stem pierced by the Velcro. After 4 weeks the pericyclic fibers of light-grown banded stems appeared less lignified, though this trend did not continue to the sixth week. Stems which had been etiolated and then banded also showed little difference from etiolated, greened stems. A striking difference between etiolated and banded stems and those in other treatments was the occurrence, after 8 to 12 weeks, of root primordia which originated just outside the vascular cambium in association with the medullary rays (Fig. $1 \mathrm{C}$ and $\mathrm{D}$ ). These primordia were found only in gaps in the sclerenchymatic sheath which were free of sclereids. Twelve weeks following etiolation, many etiolated and banded stems still lacked sclereids.

Quantitative observations. Stem diameter averaged $2.4 \mathrm{~mm}$ and did not vary significantly with shoot development, etiolation or banding (Tables 1 and 2). The width of the primary xylem decreased with shoot development, but was unaffected by banding or stem diameter. However, the width of the secondary xylem was highly correlated with stem diameter $\left(r^{2}=0.81\right)$, i.e., thicker stems contained more secondary xylem. Xylem width increased with shoot development, as might be expected, from $448 \mu \mathrm{m}$ at 4 weeks to $550 \mu \mathrm{m}$ after 12 weeks. This resulted from a 3 -fold increase (11 to 30 ) in the number of xylem elements (data not presented).

Table 4. Rooting response and anatomical changes of Carpinus betulus 'fastigiata' stems in response to stock plant shading (Expt. 2). Etiolation applied for $15 \mathrm{~d}$ following budbreak, followed by greening in full sun for $10 \mathrm{~d}$. Shading, expressed as percent of $100 \%$ light exclusion, was applied for 25 d. $1^{\circ}=$ primary; $2^{\circ}=$ secondary.

\begin{tabular}{|c|c|c|c|c|c|c|c|}
\hline \multirow[b]{2}{*}{ Parameter } & \multicolumn{5}{|c|}{ Shade treatment } & \multicolumn{2}{|c|}{ Significance $^{z}$} \\
\hline & 0 & 50 & 75 & 95 & $\overline{\text { Etiolated }}$ & $\mathrm{L}$ & $\mathrm{Q}$ \\
\hline \multicolumn{8}{|l|}{ Rooting $^{\mathrm{z}}$} \\
\hline Percent rooting & 11 & 73 & 70 & 98 & 92 & $0.0001^{*}$ & 0.27 \\
\hline Roots / rooted cutting: & 2 & 3 & 4 & 3 & 3 & $0.019^{*}$ & $0.014^{*}$ \\
\hline \multicolumn{8}{|l|}{ Measurement ${ }^{y}$} \\
\hline Stem diameter $(\mathrm{mm})$ & 1.5 & 1.5 & 1.4 & 1.2 & 1.4 & 0.52 & 0.27 \\
\hline \multicolumn{8}{|l|}{ Width of $(\mu \mathrm{m})$} \\
\hline $1^{\circ}$ xylem & 19 & 23 & 25 & 27 & 30 & $0.04^{*}$ & 0.87 \\
\hline $2^{\circ}$ xylem & 182 & 149 & 145 & 106 & 135 & $0.0001^{*}$ & 0.31 \\
\hline Phloem & 47 & 36 & 37 & 36 & 35 & $0.0001^{*}$ & $0.0003^{*}$ \\
\hline Fiber bundles & 59 & 57 & 53 & 52 & 65 & 0.41 & 0.59 \\
\hline Cortical parenchyma & 72 & 83 & 68 & 65 & 85 & $0.029^{*}$ & $0.05^{*}$ \\
\hline Collenchyma & 62 & 67 & 50 & 52 & 65 & 0.54 & 0.33 \\
\hline Periderm & 52 & 60 & 47 & 26 & 44 & $0.0001^{*}$ & $0.0001^{*}$ \\
\hline \multicolumn{8}{|l|}{ Number of } \\
\hline Fiber bundles & 19 & 16 & 14 & 16 & 16 & $0.0001^{*}$ & $0.0001^{*}$ \\
\hline Sclereids & 39 & 17 & 14 & 0 & 18 & $0.001^{*}$ & 0.92 \\
\hline \multicolumn{8}{|l|}{ Percentage of } \\
\hline Nonlignified $2^{\circ}$ xylem & 25 & 29 & 25 & 32 & 25 & 0.85 & 0.57 \\
\hline Sclereid-free gaps & 29 & 84 & 82 & 100 & 87 & $0.048^{*}$ & 0.53 \\
\hline
\end{tabular}

${ }^{\mathrm{z}}$ Rooting data based on eight replicates of eight cuttings each. Rooting evaluated after $30 \mathrm{~d}$.

yAnatomical means based on four measurements of five samples.

*Significant at $P \leq 0.05$. 
Xylem width was unaffected by etiolation but was reduced by banding. The percentage of secondary xylem remaining nonlignified decreased with shoot development, reflecting the decline of activity in the vascular cambium. This percentage was increased by etiolation, from $18 \%$ to $23 \%$ on average, but unaffected by banding. The width of the phloem averaged $62 \mu \mathrm{m}$ over the 16week period and did not vary significantly with etiolation or banding.

The width of the pericyclic fiber bundles decreased with shoot development as they were dispersed by radial expansion of the stem. This was reflected in an increase in the number of bundles. Both the width and number of fiber bundles were correlated with stem diameter $\left(r^{2}=0.18\right.$ and 0.47 , respectively $)$ and unaffected by either stock plant treatment. The width of the cortex also decreased with shoot development and radial expansion. Etiolation increased cortical width by $8 \mu \mathrm{m}$ while banding had no effect. The width of the collenchyma, which averaged $46 \mu \mathrm{m}$, did not vary significantly with shoot development or stock plant treatment. The width of the periderm increased to $53 \mu \mathrm{m}$ after 8 weeks. Etiolation reduced this by $9 \mu \mathrm{m}$ while banding had no effect.

The number of brachysclereids formed outside the medullary rays increased sharply during the first two months of shoot development and was strongly correlated with stem diameter $\left(r^{2}=0.48\right)$. More sclereids formed in the distal than the basal portion of the stem (168 vs. 124, respectively; $P=0.0001)$. There were no significant or consistent effects of etiolation or banding on sclereid number.

As radial expansion of the stem dispersed pericyclic fiber bundles, gaps formed, typically in association with phloem rays. Regardless of stock plant treatment, the percentage of these gaps remaining free of sclereids decreased dramatically as shoots developed (Table 3). Etiolation increased the percentage of sclereid-free gaps from $42 \%$ to $67 \%$ on average and delayed the decline in this percentage over time. Banding had no significant effect on the percentage of sclereid-free gaps.

\section{Experiment 2: Shading effects on shoot anatomy}

The histological changes associated with stock plant shading were similar to those described in Expt. 1. Even a moderate $(50 \%)$ exclusion of light yielded remarkable changes.

Stem diameter did not vary significantly with shading treatment (Table 4). The following variables showed positive correlations with stem diameter: width of the secondary xylem $\left(r^{2}=0.45\right)$, nonlignified secondary xylem $\left(r^{2}=0.17\right)$, cortex $\left(r^{2}=0.34\right)$, collenchyma $\left(r^{2}=0.29\right)$, and periderm $\left(r^{2}=0.38\right)$, as well as number of pericyclic fiber bundles $\left(r^{2}=0.24\right)$

The width of the primary xylem increased gradually with increasing shade while the width of the secondary xylem and phloem, and number of pericyclic fiber bundles, decreased sharply between $0 \%$ and $50 \%$ shade. As with etiolation in Expt. 1, the
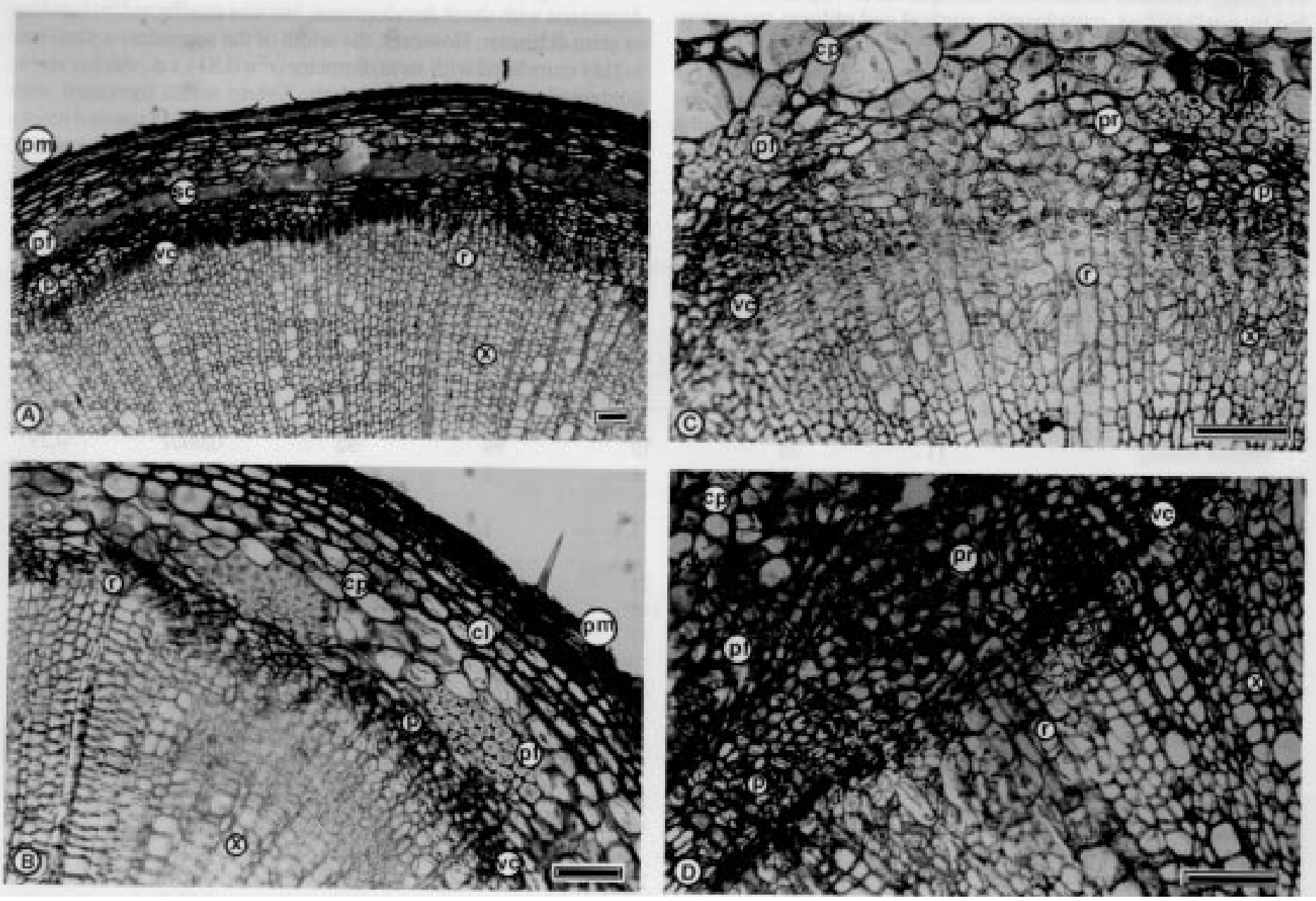

Fig. 1. Light-grown (A) and etiolated-velcro banded (B) stems of European hornbeam sampled 4 and 8 weeks, respectively, following budbreak, showing development of perivascular fibers and brachysclereids (absent in etiolated-banded stems). Adventitious root primordia were present in etiolated-velcro banded stems sampled 8 (C) and 12 (D) weeks after termination of the etiolation treatment. Stems were sectioned from paraffin at $20 \mu \mathrm{m}$ and stained with safranin and fast green. $\mathrm{x}=$ Secondary $\mathrm{xylem}$; $\mathrm{vc}=$ vascular cambium; $\mathrm{p}=$ phloem $; \mathrm{r}=$ ray; $\mathrm{pf}=$ pericyclic fibers; $\mathrm{sc}=$ brachysclereids $; \mathrm{cp}=$ cortical parenchyma; $\mathrm{cl}=$ collenchyma; $\mathrm{pm}=$ periderm. Scale bar $=50 \mu \mathrm{m}$. 
percentage of secondary xylem remaining nonlignified and the width of the pericyclic fiber bundles did not change with shading. In contrast with Expt. 1, the width of the cortical parenchyma was not increased by etiolation, and decreased significantly under higher levels of shade. Peridermal thickness decreased gradually with shade level to a minimum in shoots grown under $95 \%$ shade. The greening of etiolated shoots for 10 days increased thickness to $44 \mu \mathrm{m}$, near that of shoots grown under $75 \%$ shade.

Sclereid number decreased sharply with shade level such that sclereids were completely absent in shoots grown under $95 \%$ shade. Concomitant with the decrease in the number of sclereids, the percentage of sclereid-free gaps increased sharply with light shading, reaching $100 \%$ in shoots grown under $95 \%$ shade. The greening of etiolated shoots increased the number of sclereids and reduced the percentage of free gaps to a level near that of stems grown under $50 \%$ and $75 \%$ shade.

\section{Correlation of stem anatomy with adventitious rooting}

Experiment 1: Shoot development, etiolation, and banding effects. The anatomical parameters measured on stems just prior to their propagation were compared to the rooting achieved within the same population after $30 \mathrm{~d}$ (Tables 2 and 3). Stepwise multiple linear regression procedures were used to narrow the 13 anatomical variables down to those which were best correlated with rooting percentage and root number per rooted cutting.

Rooting percentages in Expt. 1 were best described by a linear combination of the widths of the stem, nonlignified secondary xylem, cortex and periderm $\left(r^{2}=0.79\right)$. Parameter estimates for each variable indicated that rooting percentages were directly proportional to stem diameter $(0.04 \% / \mu \mathrm{m})$, width of the nonlignified secondary xylem $(0.44 \% / \mu \mathrm{m})$, and cortex $(0.55 \% / \mu \mathrm{m})$. Rooting percentages were inversely related to peridermal thickness $(-1.6$ $\% / \mu \mathrm{m})$. Each estimate was significant at $P \leq 0.01$. Though stem diameter increased with time, and thicker stems tended to root better, overall rooting declined with shoot development. Etiolation and banding had no effect on stem diameter.

Considered separately, the percentage of sclereid-free gaps in the perivascular sclerenchyma (Table 3 ) predicted rooting response fairly well $\left(r^{2}=0.41\right)$. Percentage rooting increased by 0.8 with each percentage point increase in sclereid-free gaps. Etiolation, but not banding, increased the percentage of sclereid-free gaps in the sclerenchymatic sheath, paralleling its effect on rooting percentage and root number. On the other hand, the effect of shoot development in reducing this parameter, and rooting percentage, was dramatic.

Root numbers per rooted cutting in Expt. 1 correlated best with a combination of the percentage of sclereid-free gaps in the perivascular sclerenchyma and the width of the collenchyma $\left(r^{2}=\right.$ $0.54)$. Root number increased by 0.04 with each percentage increase in sclereid-free gaps $\left(r^{2}=0.44\right)$. Etiolated stems produced 1.2 more roots per cutting on average than light-grown stems, corresponding to an increase of 25 in the percentage of sclereidfree gaps.

Experiment 2: Shading effects. Five of the 13 anatomical parameters measured correlated well with rooting percentage $\left(r^{2}=0.99\right)$. These included stem diameter $(0.11 \% / \mu \mathrm{m})$, width of the secondary xylem $(-1.3 \% / \mu \mathrm{m})$, width of the nonlignified secondary xylem $(-1.4 \% / \mu \mathrm{m})$, width of the phloem $(-0.68 \% /$ $\mu \mathrm{m})$ and width of the cortex $(0.55 \% / \mu \mathrm{m})$. Taken alone, the percentage of sclereid-free gaps, which increased sharply with shading, again was a good predictor of percentage rooting $\left(r^{2}\right.$ $=0.57 ; 1.17 \% / \%)$. Root numbers in Expt. 2 were best correlated with a linear combination of pericyclic fiber bundle number ( -0.4 roots/no. $)$ and the width of nonlignified secondary xylem $(0.05$ roots $/ \mu \mathrm{m}$.

\section{Discussion}

The most dramatic changes observed among the anatomical parameters considered herein were in the development of the secondary xylem and sclerification with stem development, as well as in the etiolation and shading effects on lignification and sclereid formation. This study also documents, for the first time, the anatomical changes occurring in developing woody angiosperm stems in response to a range of shade levels.

Rooting percentages in each study were positively correlated with changes reflecting increased succulence of the stem, e.g., a thicker cortex, less lignification of the secondary xylem, thinner periderm and a higher percentage of sclereid-free gaps in the perivascular sclerenchyma. This succulence could be attributed to either the stock plant treatments of etiolation or shading, or to the extent of shoot development.

In Expt. 1, the widths of the secondary xylem and phloem increased as the stem developed. This correlated well with decreased rooting. In Expt. 2, the widths of the secondary xylem and phloem decreased with increasing shade level, which correlated well with increased rooting. The fact that this correlation holds both ways supports the predictive value of these parameters. The value of the amount of nonlignified xylem as a predictor of rooting is undermined, however, by the observation that better rooting was associated with more nonlignified xylem in Expt. 1, but with less nonlignified xylem in Expt. 2. The correlation of root number with the amount of nonlignified xylem also reversed between Expts. 1 and 2. However, two studies comparing easy- and difficult-to-root plants noted a higher degree of cambial activity, which might be expected to increase the proportion of nonlignified xylem, in easily-rooted stems (Bose and Mondal, 1975; Davies, 1984)

The correlation, in both studies, of increased rooting with greater stem diameter and increased cortical width supports observations Schmidt (1986) made on etiolated stems of Tilia. Our observation that etiolation delayed lignification supports the findings of Herman and Hess (1963), Reid (1923), and Smith (1924). The etiolation-induced decrease in the thickness of the periderm supports observations made by Stoutemyer in 1961 .

In the present work we used multiple regression methods to identify anatomical parameters which vary with stock plant treatments or shoot development, and which correlate well with rooting success. Hopefully, this will allow future studies to focus more attention on just a few variables. Our data suggest that width of the stem, nonlignified secondary xylem, cortical parenchyma and periderm, as well as the percentage of gaps in the sclerenchymatic sheath remaining free of sclereids ought to be considered as parameters which might correlate strongly with rooting potential in some woody angiosperms.

Within 2 to 4 weeks of budbreak, the cells of phloem rays situated between bundles of pericyclic fibers and abutting the cortical parenchyma began to accumulate safranin-positive material, presumably lignin. With lignification and loss of cytoplasm these cells became brachysclereids. Once deposited, the lignin in such cell walls apparently is not readily removed, even if the cytoplasm is retained (Esau, 1977). These sclereids always formed at the boundary of the phloem rays and cortical parenchyma, i.e., the pericycle (Fig. 1A). In cases where these cells did not differentiate into sclereids, living ray cells directly abutted the cortical parenchyma, and in transverse section a gap in the sclerenchyma sheath was apparent (Fig. 1B). When putative root primordia were 
observed in stems of Carpinus, they always developed in this region, immediately centripetal to these gaps and in association with a ray. These primordia were easily recognizable as large, densely cytoplasmic and isodiametric cells with centrally positioned nuclei and prominently staining nucleoli (Fig. 1C). As the primordium developed and included more cells, the cells of the interfascicular gap were physically incorporated into the new structure (Fig. 1D).

We hypothesize that the conflict between sclereid formation and root initiation develops at this point. Once a cell is committed to the formation of a nonliving sclereid, by deposition of lignin or loss of cytoplasm, it is incapable of being stimulated to a meristematic state and being included in the developing root primordium. In the accepted terminology of root initiation, the sclereid cell is unable to de-differentiate to a root initial cell.

In Expt. 1, it was remarkable that etiolation, applied by covering the stock plants for only the first $7 \mathrm{~d}$ of shoot development, retarded sclereid development for months afterward (Table 3). Previous research documenting a reduction in sclereid formation with etiolation (Doud and Carlson, 1977; Gomez et al., 1973; Rinallo et al., 1987) applied etiolation for longer durations. Our negative correlation of sclerification with rooting potential supports Beakbane's proposal that sclereid development may act as a developmental barrier to adventitious root initiation (Beakbane, 1961).

Of course, not all sclereid-free gaps will form root primordia, as these events depend also upon the activity of ray cells laying close to the vascular cambium. Conversely, we could propose that no sclereid-filled gaps will initiate root primordia. This is a heuristic hypothesis - too few root primordia of Carpinus have been observed to say with certainty that root initials never form in sclereidfilled regions of the pericycle. Future studies of rooting anatomy should specifically address this possibility.

White and Lovell (1984b) concluded in their work with Agathis that, "Although its precise nature has not been established, there appears to be a relationship between the presence of sclerenchymatous tissue and reduced initiation of roots. Where large areas or bands of sclerenchyma are present in a cutting, rooting is generally difficult. Thus from a practical point of view it would be beneficial if the parent plant could be grown under conditions which are not conducive to sclerenchyma production." This approach remains the state of the art today.

\section{Literature Cited}

Beakbane, A.B. 1961. Structure of the plant stem in relation to adventitious rooting. Nature 192:954-955.

Beakbane, A.B. 1969. Relationship between structure and adventitious rooting. Proc. Intl. Plant Prop. Soc. 19:192-201.

Bose, T.K. and D.P. Mondal. 1975. Anatomy of stem in relation to adventitious rooting. Plant Sci. 7:23-27.

Brutsch, M.O., P. Allen, and B.N. Wolstenholme. 1977. The anatomy of adventitious root formation in adult-phase pecan (Carya illinoensis (Wang.) K. Koch) stem cuttings. Hort. Res. 17:23-31.

Ciampi, C. and R. Gellini. 1958. Anatomical study on the relationship between structure and rooting capacity in olive cuttings. Nuovo Giorn. Botan. Ital. 65:417-424.
Davies, Jr., F.T. 1984. Shoot RNA, cambial activity and indolebutyric acid effectivity in seasonal rooting of juvenile and mature Ficus pumila cuttings. Phys. Plant. 62:571-575.

Davies, Jr., F.T., J.E. Lazarte, and J.N. Joiner. 1982. Initiation and development of roots in juvenile and mature leaf bud cuttings of Ficus pumila L. Amer. J. Bot. 69:804-811.

Doud, S.L. and R.F. Carlson. 1977. Effects of etiolation, stem anatomy, and starch reserves of root initiation of layered Malus clones. J. Amer. Soc. Hort. Sci. 102:487-491.

Edwards, R.A. and M.B. Thomas. 1980. Observations on physical barriers to root formation in cuttings. Plant Prop. (2):6-8.

Esau, K. 1977. Anatomy of seed plants. 2nd ed. Wiley, New York, N.Y. Girouard, R.M. 1967. Initiation and development of adventitious roots in stem cuttings of Hedera helix. Anatomical studies of the mature growth phase. Can. J. Bot. 45:1883-1886.

Gomez, R.E., J. Soule, and S.E. Malo. 1973. Anatomical aspects of avocado stems with reference to rooting. Proc. Trop. Region Amer. Soc. Hort. Sci. 17:23-28.

Goodin, J.R. 1965. Anatomical changes associated with juvenile-tomature growth phase transition in Hedera. Nature 208:504-505.

Haissig, B.E. 1973. Origins of adventitious roots. N.Z. J. For. Sci. 4:299310.

Herman, D.E. and C.E. Hess. 1963. The effect of etiolation upon the rooting of cuttings. Proc. Intl. Plant Prop. Soc. 13:42-62.

Johansen, D.A. 1940. Botanical microtechnique. McGraw-Hill, New York.

Lovell, P.H. and J. White. 1986. Anatomical changes during adventitious rooting. In: New root formation in plants and cuttings, p. 223-253. In: Michael B. Jackson (ed.). Developments in plant and soil science . vol. 20. Martinus Nijhoff Publ., Dordrecht.

Maynard, B.K. and N.L. Bassuk. 1987. Stock plant etiolation and blanching of woody plants prior to cutting propagation. J. Amer. Soc. Hort. Sci. 112:273-276.

Maynard, B.K. and N.L. Bassuk. 1992. Stock plant etiolation, shading, and stem banding effects on cutting propagation of Carpinus betulus. J. Amer. Soc. Hort. Sci. 117:740-744.

Nanda, K.K., V.K. Anand, and P. Kumar. 1970. Some investigations of auxin effects on rooting of stem cuttings of forest plants. Indian For. 96:171-187.

Reid, O. 1923. The propagation of camphor by stem cuttings. Trans. Proc. Bot. Soc. Edin. 28:184-188.

Rinallo, C., R. Gellini, and A. Fabbri. 1987. Studies on rhizogenesis in Castanea sativa Mill. cuttings. Adv. Hort. Sci. 1:27-33.

Sachs R.M., F. Loreti, J. de Bie. 1964. Plant rooting studies indicate sclerenchyma is not a restricting factor. Calif. Agr. September:4-5.

SAS Institute. 1985. SAS user's guide: Statistics. 5th ed. SAS Institute, Cary, N.C.

Schmidt, G. 1986. Effect of etiolation on the histological structure of the stem of Tilia tomentosa Moench. Folia Dendro. 13:217-262.

Smith, E. P. 1924. The anatomy and propagation of Clematis. Trans. Proc. Bot. Soc. Edin. 29:17-26.

Snedecor, G.W. and W.G. Cochran. 1980. Statistical methods. 7th ed. Iowa State Univ. Press, Ames.

Stoutemyer, V.T. 1961. Light and propagation. Proc. Intl. Plant Prop. Soc. 11:252-260.

Vieitez, E. 1974. Los teijos mechanicos de las estaquillas como posibles reguladores de su capacidad de rizogenesis. Ser. Recursos Nat. 1:65-93. White, J., and P.H. Lovell. 1984a. The anatomy of root initiation in cuttings of Griselinia littoralis and Griselinia lucida. Ann. Bot. 54:7-20.

White, J., and P.H. Lovell. 1984b. Anatomical changes which occur in cuttings of Agathis australis (D. Don) Lindl 2. The initiation of root primordia and early root development. Ann. Bot. 54:633-645. 